\title{
Assessing the Efficiency of Ateel Wastewater Treatment Station and Its Suitability for Rehabilitation Improving Water Quality and Its Safe and Practical Application
}

\author{
Orwa Jaber Houshia ${ }^{1^{*}}$, Mohammed Boufaroua $^{2}$, Abdallah Alimari ${ }^{2}$ \\ and Nahawand Souqia ${ }^{3}$ \\ ${ }^{1}$ Department of Chemistry, Arab American University, P.O. Box 240, Jenin, Palestine. \\ ${ }^{2}$ International Center for Agricultural Research in the Dry Areas (ICARDA). \\ ${ }^{3}$ National Agricultural Research Center, Jenin, Palestine.
}

\begin{abstract}
Authors' contributions
This work has been a collaboration between the National Agricultural Research Center (NARC) scientists and the Arab American University professors, with generous financial support from the International Center for Agricultural Research in the Dry Areas (ICARDA).

Sample collection and analysis were performed by Motasem Zaid (analytical chemist),

Odayy Zaid (Biochemist), Jaber Alimoor (Microbiologist), and Raed Alary (Engineer). The project was coordinated by author NS and directed by ICARDA representative in Palestine

author AA. The project advisor was author OJH (Organic chemist) at the Arab American University. All authors read and approved the final manuscript.
\end{abstract}

\begin{abstract}
In regions where water is in short supply, wastewater treatment offers the possibility for the efficient removal of unwanted pollutants and germs so that the water may be used for irrigation. Water scarcity is an old problem in Palestine because of various geographical settings and political turbulence. The problem is compounded by population growth and development. As a result of the increasing demand for water, using alternative options has become a must to meet water needs. The demand for water can be reduced by increasing the efficiency of water use and by making usable sources of water previously considered unusable. One possible supply is 'wastewater'. This project sets out to treat and reclaim wastewater as a supply of irrigation water and thus enhance crop production. The project
\end{abstract}


results reveal that wastewater from the Ateel wastewater station potentially can be used for irrigating crops. It offers many social and financial benefits for improving the farmers' sources of revenue. Various parameters were monitored and measured for the Ateel wastewater station and yielded some interesting and promising data.

Keywords: Treated wastewater; irrigation; agriculture; cropping.

\section{INTRODUCTION}

Nowadays most arid and semi-arid regions are facing water problems and conditions are very severe, especially in developing countries. These areas are facing difficult challenges in meeting rising demands for water as the available supplies of freshwater have been depleted because of extended droughts, population growth, more stringent health-based regulations, and competing demands from a variety of users [1,2]. Palestine is one such area that fits this profile and urgent options for wastewater treatment need to be considered to avert threats to sustainable development [3]. Furthermore, wastewater treatment may help reduce the contamination of groundwater. In the West Bank, groundwater is considered the main source of water, so it is vital to preserve its quality and prevent deterioration and pollution, especially from human activities.

This project sought to repair a neglected wastewater treatment station in the city of Ateel in the Tulkarm Governorate (northern West Bank), Palestine by evaluating the wastewater before and after treatment. Thus, one objective of the study was to measure the efficiency of the station. Ateel city has a population of 12,900 residents. The Ateel wastewater station accumulates water from 35 houses connected to the network. The average monthly house consumption of fresh water is about $623 \mathrm{~m}^{3}$. The average daily consumption of the house is about $20.77 \mathrm{~m}^{3}$. Each house consumes about $0.6 \mathrm{~m}^{3}$, on average. The average station intake (the amount coming from the households) is about $70 \%$ of the daily consumption about $14.5 \mathrm{~m}^{3}$. Water quality was monitored using several parameters and indicators.

This station was built in an area that has low rainfall and a low socioeconomic status, even though it is considered an agricultural region. Therefore, our intention was not only to rehabilitate the station, but to use the water for agricultural purposes and to change negative public perceptions about recycled wastewater to positive ones. This will help create better public awareness which will address the water problem effectively. Education and awareness-building campaigns play a critical role in building public knowledge and support for new water solutions. Poor water quality may negatively affect productivity because of illness, social and societal decay, and declines in public order. Increased media attention, community pressure, and education about the effects of water quality might lead to more support for the concept that is worth investing capital to protect public health and water quality by constructing wastewater treatment stations.

\section{MATERIALS AND METHODS}

\subsection{Site Selection}

Ateel city, located in the northern West Bank, was considered for this project for various reasons: 
- An existing wastewater station close to the national agricultural research center was convenient for data gathering and monitoring.

- The area is considered one of the most active agricultural regions in Palestine.

- The willingness of farmers to use treated wastewater for certain crops was a plus.

- The region has $s$ fertile soil and practices rain-fed agriculture, but it has limited water resources.

\subsection{Description of the Ateel Wastewater Station}

The station consists of several stages of wastewater treatment. The first stage is the 'inlet manhole'. Its purpose is to trap/remove and/or isolate large objects which might contaminate the station. The second stage is the 'septic tank' sedimentation process consisting of two compartments. Its purpose is to separate suspended solids (sludge) from the liquid middle layer and the top grease layer. This stage is referred to as the primary treatment. The next compartment is the 'up flow trickling filter' which is filled with gravel that works as a natural sieve. This compartment has two sections. One is in use, and the second is held in reserve and is used if the first one is blocked. The next stage consists on a 'trickling filter' which serves to eliminate any small organic and dissolved matter by converting it to proteins. It serves as an efficient treatment for $60 \%$ of the pollutants. The next stage is the 'sand filter' compartment which eliminates micro-organisms and other impurities. This compartment reduces any bad odors which might be associated with the treatment process. The last step is the 'storage tank' which holds the water until it is needed. Diagram 1 shows a schematic sketch of the treatment process.

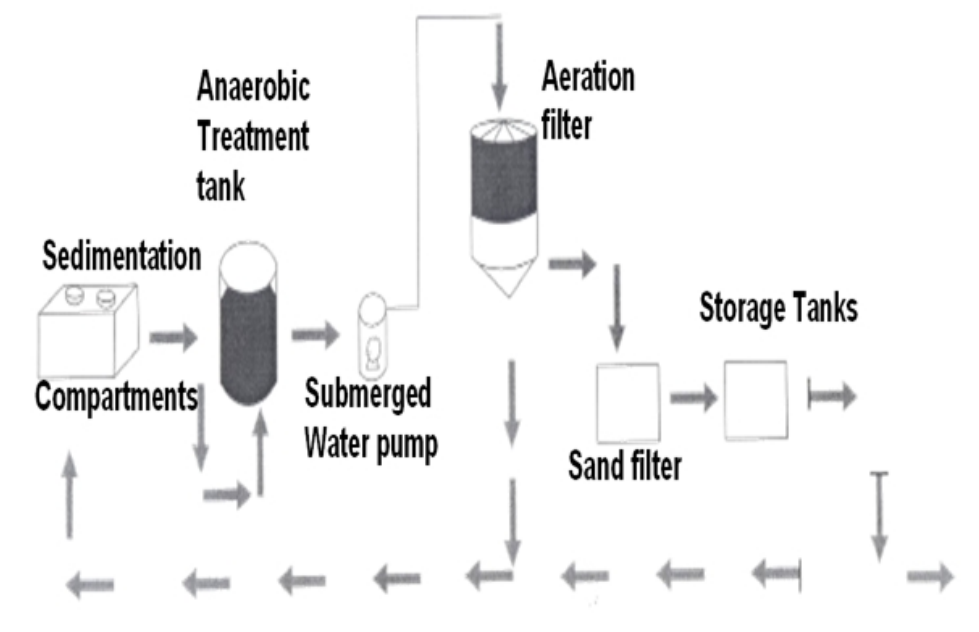

Diagram 1. Sketch of ateel wastewater treatment station

\section{RESULTS AND DISCUSSION}

There are two main sources of fresh water for Ateel city - annual rainfall and the underground water source. The average annual rainfall is shown in Table 1. During the past ten year the average rainfall has been about $607 \mathrm{~mm}$. The rate of supply of underground water ranges from 80 to $100 \mathrm{~m}^{3} /$ hour for each well. There are six underground water wells which are privately owned. The water network system within the town is old, and covers $97 \%$ of the buildings. The average consumption of fresh water in the town reaches $24,430.55$ 
$\mathrm{m}^{3} /$ month. The average individual uses 87.62 liter/day. The water loss from leaks amounts to about $31.37 \%$ of the total. It can be seen that the area has limited freshwater sources, and that a wastewater treatment plant might come in handy for supporting the existing options.

Table 1. Average annual rainfall at ateel

\begin{tabular}{ll}
\hline Year & Average rainfall $(\mathbf{m m})$ \\
\hline $1999 / 00$ & 517.7 \\
$2000 / 01$ & 548.2 \\
$2001 / 02$ & 697 \\
$2002 / 03$ & 970 \\
$2003 / 04$ & 573.5 \\
$2004 / 05$ & 557 \\
$2005 / 06$ & 588 \\
$2006 / 07$ & 550 \\
$2007 / 08$ & 470 \\
$2008 / 09$ & 488 \\
$2009 / 10$ & 717 \\
\hline
\end{tabular}

Wastewater contains organic substances, typically in the form of carbon, hydrogen, oxygen, and nitrogen and may contain other elements. Common concentrations of these organic materials in grey water are in the form of proteins (40 to $60 \%$ ), carbohydrates (25 to $50 \%$ ), and oils and fats (8 to 12\%). The water may also contain small amounts of synthetic organic molecules (such as pesticides and solvents), which may range from simple to complex in structure. Biochemical oxidation reactions convert organic material using oxygen and nutrients into carbon dioxide, water, and new cells. This process can be expressed as:

$$
\text { Organics }+\mathrm{O}_{2}+\text { nutrients } \rightarrow \mathrm{CO}_{2}+\mathrm{H}_{2} \mathrm{O}+\text { new cells }+ \text { nutrients + energy }
$$

In this equation, one can assume that the organisms use oxygen to breakdown carbonbased materials for incorporation into new cell mass and energy. A frequent measure of this oxygen use is the biochemical oxygen demand (BOD). BOD is defined as the amount of oxygen used in the metabolism of biodegradable organics. If water with a large BOD is discharged into the environment, it can deplete the natural oxygen resources. Heterotrophic bacteria use the deposited organics and oxygen at rates that exceed the oxygen-transfer rates across the water surface. This can cause anaerobic conditions, which lead to noxious odors and a degradation of the water quality.

Water samples were analyzed before and after treatment. The following indicators were included in these measured parameters:

- $\quad$ BOD recorded over five days $\left(\mathrm{BOD}_{5}\right)$.

- Total suspended solids (TSS) or total dissolved solids (TDS).

- Thermo-tolerant coliforms or E. coli (an indicator of fecal contamination) forming units (cfu/100 mL).

- Anions, such as residual chlorine and carbonates.

- Cations and water hardness, such as sodium, potassium, calcium, and magnesium cations. 
Table 2 shows the values of the various parameters tested for. The data indicate a significant variation in all parameters. Fig. 1 shows the cation concentration measured before and after treatment, while Fig. 2 illustrates the anion measurements. The most interesting results are shown in Fig. 3 and Fig. 4 indicating an effective biological treatment. The efficiency of the treatment in the station is shown in Fig. 5 which indicates the removal capacity of the treatment unit.

Table 2. An example of values of parameters measured on three days

\begin{tabular}{lllllll}
\hline Date $\mathbf{l}$ & $\mathbf{1 0 / 2 5 / 2 0 1 1}$ & $\mathbf{3 / 2 5 / 2 0 1 2}$ & $\mathbf{6 / 1 9 / 2 0 1 2}$ \\
\cline { 2 - 7 } Parameter & Before & After & Before & After & Before & After \\
\hline $\mathrm{pH}$ & 6.83 & 7.41 & 7.59 & 7.88 & 7.78 & 7.80 \\
$\mathrm{EC}(\mathrm{mS} / \mathrm{cm})$ & 1.60 & 1.60 & 1.20 & 1.40 & 1.75 & 1.87 \\
$\mathrm{TDS}(\mathrm{ppm})$ & 1024 & 987 & 896 & 768 & 1197 & 1120 \\
$\mathrm{Cl}(\mathrm{ppm})$ & 155.98 & 191.43 & 156.00 & 152.4 & 131.165 & 136.48 \\
$\mathrm{Hardness}$ & 340.00 & 380.00 & 335.00 & 365.00 & 922.5 & 892.5 \\
$\mathrm{Ca}(\mathrm{ppm})$ & 67.32 & 73.44 & 69.36 & 61.20 & 71.40 & 102 \\
$\mathrm{Mg}(\mathrm{ppm})$ & 42.14 & 48.16 & 39.7 & 51.8 & 115.26 & 98.94 \\
$\mathrm{HCO}_{3}(\mathrm{ppm})$ & 1,342 & 677.1 & 384.3 & 603.9 & 14.64 & 8.845 \\
$\mathrm{NO}_{3}(\mathrm{ppm})$ & 81.90 & 46.80 & 96.9 & 58.9 & 43.00 & 25.00 \\
$\mathrm{~K}(\mathrm{ppm})$ & 12.5 & 21.8 & 34.5 & 17.3 & 26.0 & 12.0 \\
$\mathrm{Na}(\mathrm{ppm})$ & 244.00 & 118.60 & 110.8 & 107 & 170 & 110 \\
$\mathrm{PO}(\mathrm{ppm})$ & 40.52 & 95.90 & 49.20 & 37.10 & 37.00 & 31.25 \\
$\mathrm{Total} \mathrm{coli}(\mathrm{cfu})$ & 150,000 & 3,200 & 160,000 & 2,500 & 150,000 & 2,700 \\
$\mathrm{E} . \mathrm{coli}(\mathrm{ppm})$ & 563.00 & 205.00 & 446.00 & 225.00 & 2,300 & 600 \\
$\mathrm{COD}(\mathrm{ppm})$ & $1,180.00$ & 430.00 & $1,098.00$ & 360.00 & 1,525 & 139 \\
$\mathrm{BOD}_{5}(\mathrm{ppm})$ & 815.00 & 100.00 & 750.00 & 100.00 & 637 & 60 \\
\hline
\end{tabular}




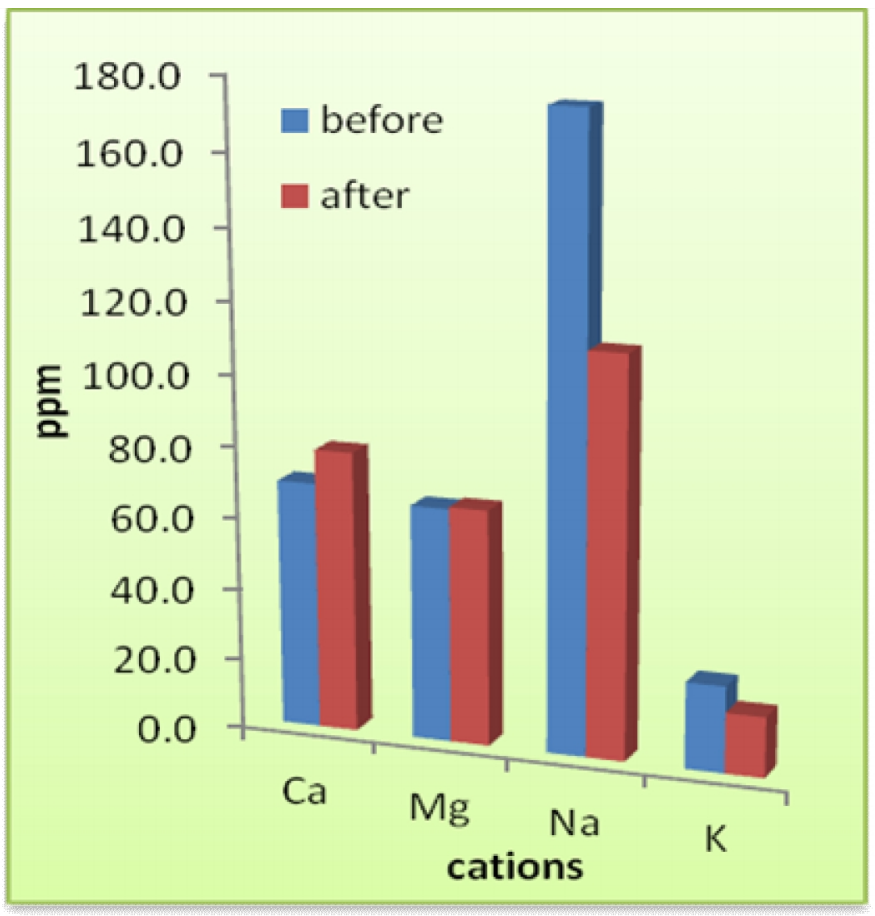

Fig. 1. Concentration of the cations ( $x$-axis) in parts per million (ppm, y axis)

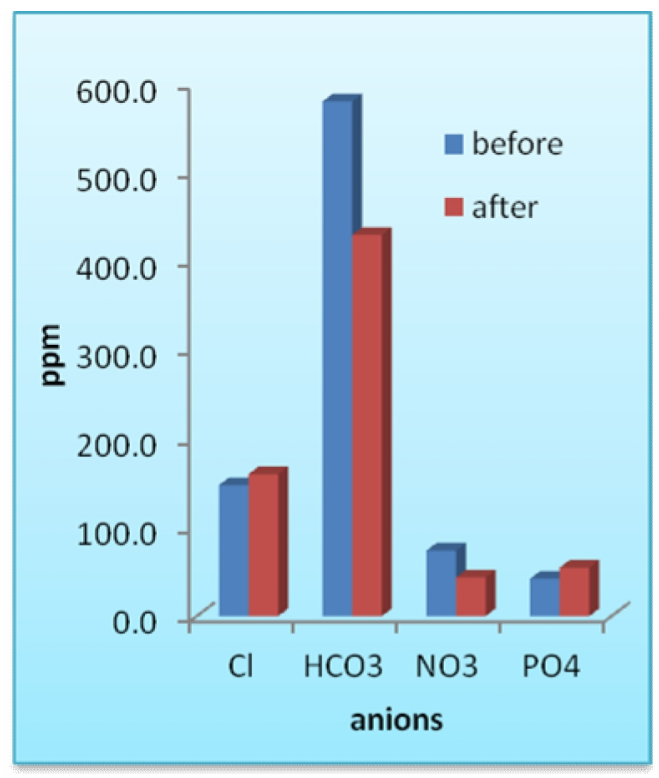

Fig. 2. Concentration of anions (x-axis) in parts per million (ppm, y-axis) 


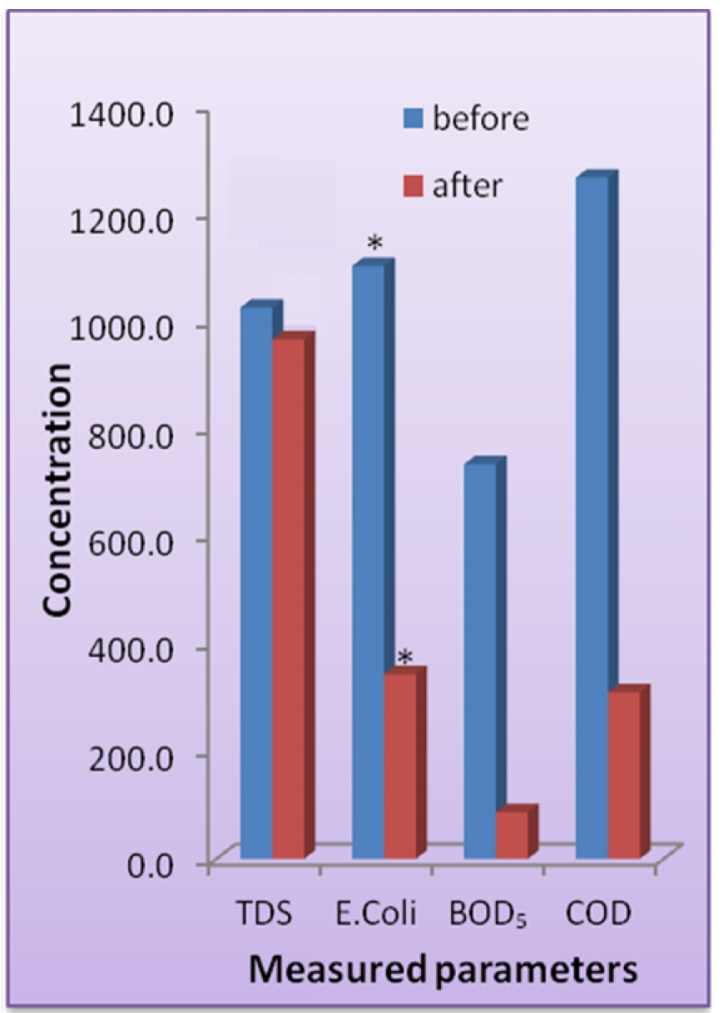

Fig. 3. Concentration of indicators in ppm except for *Ecoli in cfu

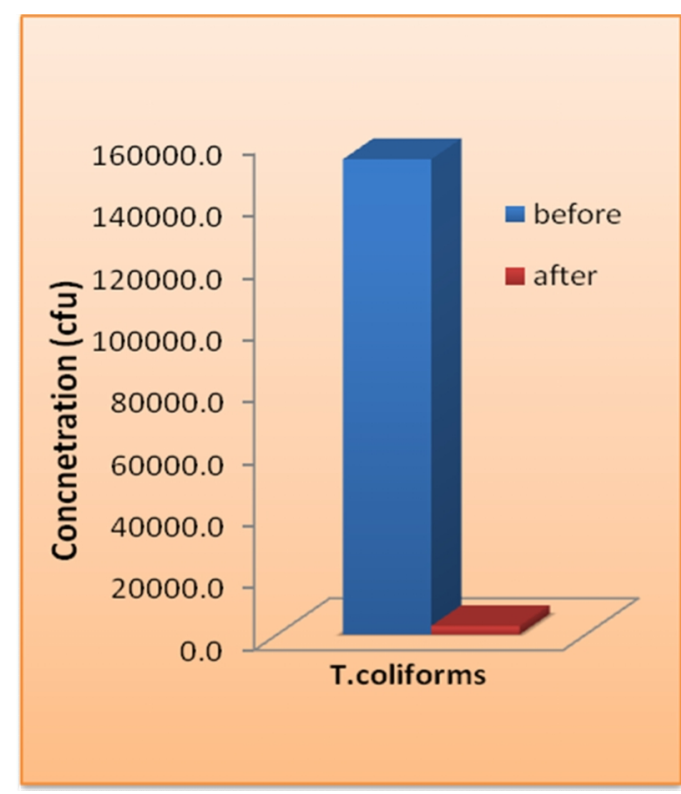

Fig. 4. Comparing the total coliforms concentrations before and after treatment 


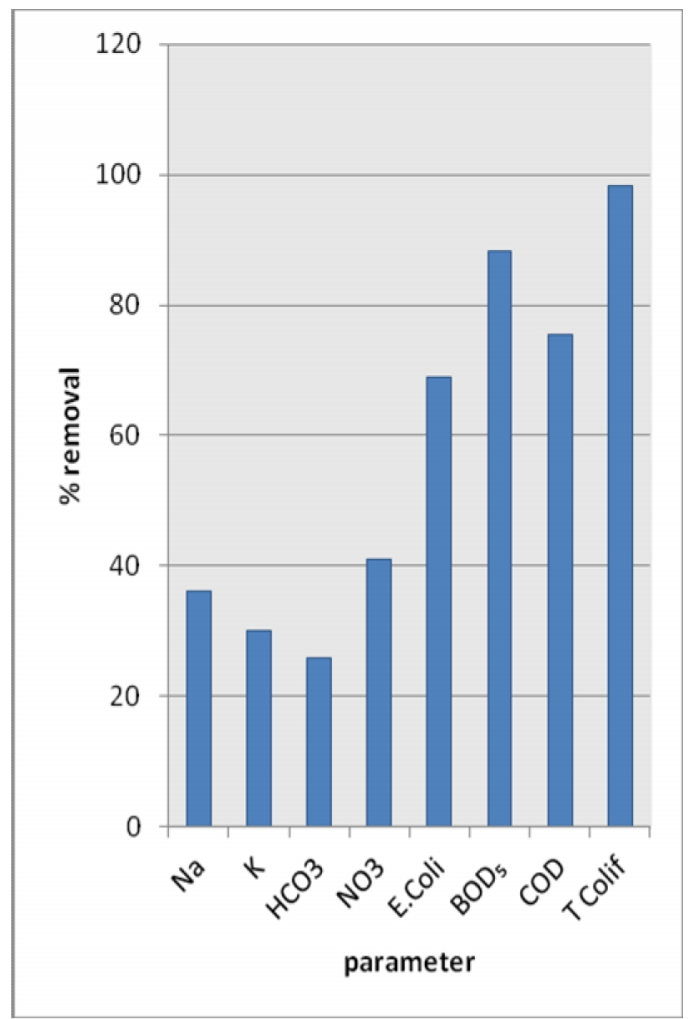

Fig. 5. Average efficiency of the station for the removal of various parameters

The mean efficiency of $\mathrm{BOD}_{5}$ removal over several periods was $88 \%$. The average $\mathrm{BOD}_{5}$ removal over the entire period for all samples was $87 \mathrm{mg} / \mathrm{L}$ (ranging from $60 \mathrm{mg} / \mathrm{L}$ to 100 $\mathrm{mg} / \mathrm{L}$ ) after treatment. Typical $\mathrm{BOD}_{5}$ values for grey water, as reported in the literature, range from 33 to $290 \mathrm{mg} / \mathrm{L}$, while values for untreated domestic wastewater range from 100 to $400 \mathrm{mg} / \mathrm{L}$ [5]. The $\mathrm{BOD}_{5}$ of the wastewater sampled just prior to discharge to the fields averaged $87 \mathrm{mg} / \mathrm{L}$ with a range of 60 to $100 \mathrm{mg} / \mathrm{L}$. The measurements before treatments had a range of from 600 to $800 \mathrm{mg} / \mathrm{L}$. This gives the station an average efficiency of $88 \%$. It is worth noting the E. coli chemical oxygen demand (COD) readings which also were lowered appreciably. Another interesting result was the considerable lowering in total coliforms as indicated in Fig. 5. No significant change with respect to TDS, which ranged from 700 to $1200 \mathrm{mg} / \mathrm{L}$, was observed. Total Coliform counts generally were high and exceeded our dilution ranges. Guideline [6] for Fecal Coliforms in reclaimed water for irrigation is set at $200 \mathrm{cfu} / 100$. Jefferson et al. published data showing suggested appropriate values for wastewater recycling of $<10,000$ and $<2,000 \mathrm{cfu} / 100 \mathrm{~mL}$ for TC and FC, respectively [7].

Many of the micro-organisms that exist in wastewater might be beneficial. In fact, many wastewater treatment technologies depend on these beneficial micro-organisms for remediation of wastewater, so that it does not destructively affect the environment. One of the primary purposes of water treatment systems is to remove organic matter from wastewater so that excessive oxygen consumption will not become a problem when it is released to the environment. Another objective of these treatment systems is 
nitrification/denitrification. Nitrification is an aerobic route in which bacteria oxidize reduced forms of nitrogen $\left(\mathrm{NH}_{4}{ }^{+}, \mathrm{NO}_{2-}^{-}\right.$, and $\left.\mathrm{NO}_{3}^{-}\right)$. Denitrification is an anaerobic route by which oxidized forms of nitrogen are reduced to gaseous forms $\left(\mathrm{NO}_{3^{-}}, \mathrm{NO}_{2^{-}}, \mathrm{N}_{2} \mathrm{O}\right.$ or $\left.\mathrm{N}_{2}\right)$, which can then escape into the atmosphere. This is important because the release of nitrogen to the aquatic environment can also cause eutrophication. This is really not so important in our case, since the water will be used for direct irrigation rather than being released into streams. The efficiency of the nitrates removal is shown in Fig. 7 along with the efficiency of removal of the rest of the parameters.

The treated wastewater was used for irrigating sorghum crops as shown in Figs. 6 and 7. Characterization of these crops will be the subject of another paper.

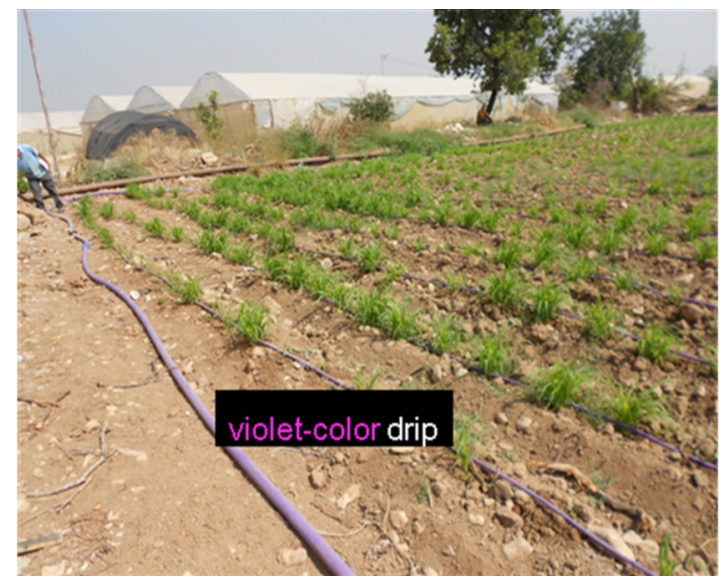

Fig. 6. One week old sorghum crop

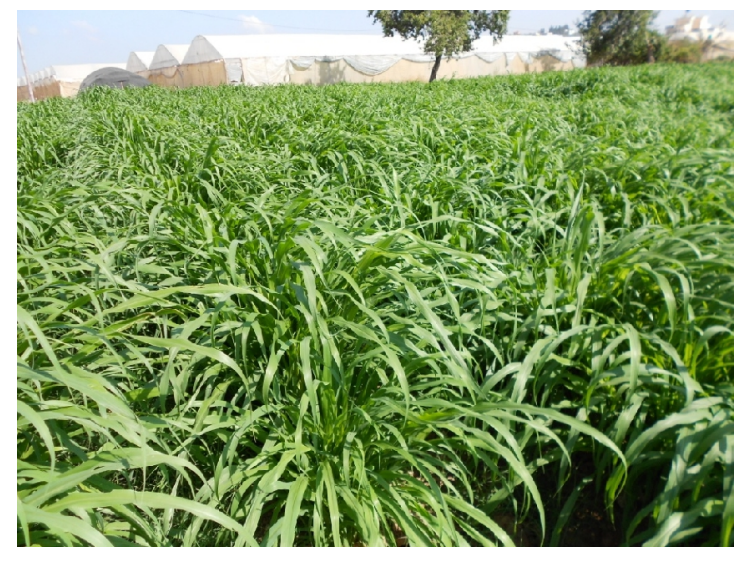

Fig. 7. Sorghum crop irrigated with treated wastewater after $\mathbf{4 5}$ days

\section{CONCLUSIONS}

The treatment station in Ateel city was evaluated and several important parameters were measured. Overall, the results were reasonably good for such an under-maintained or neglected station and they seem to be consistent and compatible with Palestinian 
standards. Interviews with community members and farmers indicated wide community interest in using the treated wastewater, especially after observing the positive growth in the sorghum crops.

Using treated wastewater from renovated water treatment plants might be a promising strategy for achieving significant local water savings and reducing the risk of water borne diseases, especially in marginalized rural areas. Research on further economic benefits is underway to understand the real financial returns to farmers and the community as a whole.

\section{ACKNOWLEDGEMENTS}

The researchers would like to thank Dr. Nasri Haddad and ICARDA for their generous support. We would also like to thank the city of Ateel for its cooperation in this research. Great appreciation is also expressed to Motasem Zaid, Odayy Zaid, Jaber Alimoor, and Raed Alary, without whom, this would have not been accomplished.

\section{COMPETING INTERESTS}

Authors have declared that no competing interests exist.

\section{REFERENCES}

1. United States Department of the Interior, Bureau of Reclamation and Sandia National Laboratories. Desalination and water purification technology roadmap - a report of the Executive Committee. Desalination \& Water Purification Research \& Development Program Report \#95. Denver, CO: United States Department of the Interior, Bureau of Reclamation, Water Treatment and Engineering Group; 2003.

2. United States Environmental Protection Agency, 1999. Alternative disinfectants and oxidants guidance manual. Office of Water Report 815-R-99-014. Washington DC; EPA Office of Water.

3. Al-Jayyousi OR. Greywater reuse: towards sustainable water management, Desalination. 2003;156(1-3):181-192.

4. United States Environmental Protection Agency,. Microbial and disinfection by-product rules. Federal Register. 1998;63(241):69389-69476.

5. Siegrist RL. Waste segregation as a means to enhance onsite wastewater management. Journal of Environmental Health. 1977;40(1):5-9. Pages 2-6 in National Small Flows Clearinghouse 1998. Greywater Technology Package WWBKNG 82.

6. Dixon AM, Butler D, Fewkes A. Guidelines fro greywater reuse: Health issues. Water and Environmental Management. 1999;15(5):322-326.

7. Jefferson B, Laine AL. Stephenson T, Judd SJ. "Advanced biological unit processes for domestic wastewater recycling" Water Science and Technology. 2001;43(10):211218.

(C) 2013 Houshia et al.; This is an Open Access article distributed under the terms of the Creative Commons Attribution License (http://creativecommons.org/licenses/by/3.0), which permits unrestricted use, distribution, and reproduction in any medium, provided the original work is properly cited.

Peer-review history:

The peer review history for this paper can be accessed here: http://www.sciencedomain.org/review-history.php?iid=210\&id=5\&aid=1238 